Innes, J. R. M. \& Shearer, G. D. (I940). F. comp. Path. Ther. 53, 1.

Lillie, R. D. (1965). Histopathologic Technique and Practical Histochemistry, 3rd ed., p. 460. Maidenhead, Berks.: McGraw-Hill.

McDonald, I. W. (r942). Aust, vet. F. 18, 165.

Schwedenberg, T. H. (1959). Э. Neuropath. exp. Neurol. 18, 597.

Spais, A., Palsson, P. A. \& van Bogaert, L. (r96r). Acta Neuropath. 1, 56.

Young, S. \& Cordy, D. R. (1964). F. Neuropath. exp. Neurol. 23, 635 .

\title{
Recent studies on galactosaemia, phenylketonuria and homocystinuria
}

\section{By L. I. Woolf (Member of the External Staff, Medical Research Council), Department of the Regius Professor of Medicine, The Radcliffe Infirmary, Oxford}

Galactosaemia, phenylketonuria and homocystinuria are inborn errors of metabolism as the term was defined by Garrod (1908). In all three lack of an enzyme causes a metabolic block and accumulation of the substrate of the missing enzyme, and all three are inherited as Mendelian recessive characters. Unlike Garrod's original examples, galactosaemia, phenylketonuria and homocystinuria are often accompanied by damage to the central nervous system and the majority of those affected are mentally retarded (Woolf, 1962a, 1963; Gerritsen \& Waisman, 1966).

\section{Galactosaemia}

Basic biochemistry. Galactose is converted into glucose, mainly in the liver but to some extent in many other tissues. The first step is phosphorylation to galactoseI-phosphate, a reaction catalysed by galactokinase. Galactose-1-phosphate reacts in the presence of galactose-1-phosphate uridylyltransferase, with uridyl diphosphate glucose, to yield uridyl diphosphate galactose, and this is converted into uridyl diphosphate glucose by the enzyme epimerase. In galactosaemia the second enzyme, galactose-I-phosphate uridylyltransferase, is absent or inactive. In consequence galactose-I-phosphate accumulates intracellularly and, by feed-back inhibition of galactokinase, causes the accumulation of galactose in all the body fluids.

Galactose-I-phosphate acts as a competitive inhibitor of phosphoglucomutase, blocking, to an extent depending on the relative concentrations, the main route for utilization of glucose- I-phosphate and glycogen.

Clinical features. In general, infants with galactosaemia fail to gain weight properly, their livers are enlarged, and often they are jaundiced. They may die in liver failure during the first few weeks or months of life. Survivors develop cataracts and show some renal tubular dysfunction. The cataracts may be the result of accumulation of dulcitol in the lens. Almost all surviving untreated galactosaemics are mentally retarded, with intelligence quotients (IQ) 30-70. Apart from this retardation, there is very little evidence of damage to the central nervous system, perhaps because only the less severely affected survive beyond infancy. If treatment is started in early infancy, about two-thirds of the patients have normal intelligence; the longer the time between birth and start of treatment, the lower the final IQ. 
In some patients deprived of milk or other galactose-containing food from birth, the intelligence nevertheless remains low, suggesting some prenatal damage to the brain. Coupled with this is the finding by Hsia \& Walker (196r) that the birth weights of galactosaemic infants were less than those of their unaffected siblings and that the death rate was still high in infancy even with treatment from birth. Galactose-I-phosphate, the probable toxic substance in galactosaemia, does not pass readily through cell membranes and remains or is metabolized in the cell in which it is formed. Thus, if a foetus lacks the transferase and galactose is circulating in the maternal blood, the galactose will cross the placenta, enter the foetal cells and accumulate there as galactose-I-phosphate (Schwarz, I960). It is advisable, therefore, to give the mother of a galactosaemic infant a galactose-free diet during subsequent pregnancies.

Screening the newborn. It has been recommended that all newborn infants be tested for galactosaemia so that, where necessary, treatment can be started at the earliest possible moment. Since the prevalence of galactosaemia is only i in 70000 live births, such screening programmes are usually set up in conjunction with screening for phenylketonuria and other inborn errors of metabolism. Galactose is sought in urine or blood, either by chromatography or microbiological assay. In a recent method, Beutler, Baluda \& Donnell (I964) describe a simple direct test for the enzyme galactose-I-phosphate uridylyltransferase, that can be carried out on cord blood; this may well be the screening method of choice for galactosaemia.

Genetics. Direct assay of transferase in the red blood cells shows that about half of all galactosaemics have no detectable transferase activity and the other half have between 3 and $12 \%$ of normal enzyme activity. There seems to be little or no correlation between the level of this residual activity and the degree of clinical severity. A difficulty of interpretation of enzyme assays is that we do not know how closely the enzyme content of erythrocytes corresponds to that of liver cells in different individuals. This is made evident by the existence of symptomless heterozygotes with transferase levels in their red cells in the galactosaemic range, of heterozygotes with apparently normal enzyme levels but marked intolerance to galactose and of individuals with all the clinical and biochemical features of galactosaemia except for normal enzyme levels in their red cells (Woolf, 1962a).

Beutler, Baluda, Sturgeon \& Day (1965) described the Duarte variant, a gene that, in the homozygous state, causes the transferase level in the red cell to be about half normal. The simplest explanation is that this genc is allelic with the galactosaemia gene and the normal gene coded for the transferase and that the Duarte gene codes for a less efficient variant of the enzyme. There may be a large number of different alleles at this locus, some, like the Duarte gene, without perceptible clinical effect.

Alternative pathways of galactose metabolism. When $\left[1-{ }^{14} \mathrm{C}\right]$ galactose is administered to most galactosaemics, the ${ }^{14} \mathrm{CO}_{2}$ content of their expired air is, on the average, $13 \%$ of normal. This indicates that pathways for galactose metabolism exist independent of the transferase; some of these alternative pathways have been worked out. 
Segal and his co-workers have described a select group of patients presenting in infancy with typical symptoms of galactosaemia and with no transferase in their red cells who can metabolize labelled galactose to ${ }^{14} \mathrm{CO}_{2}$ as fast as normal individuals (Segal, Blair \& Roth, 1965). Family studies showed that some clinically unaffected siblings of these patients also lacked transferase yet could metabolize galactose at the normal rate. All these individuals are negroes and the condition has been termed the 'negro variant' of galactosaemia. It seems probable that the enzyme catalysing one of the alternative pathways of galactose metabolism is present in much greater amount in some populations than in others, because of gene variation.

\section{Galactokinase deficiency}

Gitzelmann $(1965)$ has recently described a new inborn error of galactose metabolism-absence of galactokinase. The galactose content of blood and urine was as high as in galactosaemia, but the blood had no galactose-I-phosphate. Clinically, the patient suffered from cataracts but was otherwise well, of normal intelligence and without liver disease. This condition has been termed the 'Swiss-variant of galactosaemia'.

\section{Phenylketonuria}

Biochemistry. Normally the first step in phenylalanine metabolism is oxidation to tyrosine, a reaction catalysed by phenylalanine 4-hydroxylase. In phenylketonuria, discovered by Fölling (1934), this enzyme is absent or inactive and phenylalanine therefore accumulates. The high concentration of phenylalanine in the tissues causes reactions such as transamination, decarboxylation and acetylation to proceed at appreciable rates; normally these reactions make a negligible contribution to the metabolism of phenylalanine. The direct and indirect products of these reactions, so-called 'abnormal' metabolites such as phenylpyruvic acid, phenylacetylglutamine and $o$-hydroxyphenylacetic acid, are excreted in the urine.

Clinical features. Typically, phenylketonuria is characterized by profound mental retardation after a few months of age, though the patients are normal at birth. The majority of older phenylketonurics have an IQ below 30 . Many show disturbances of behaviour that may approach the psychotic. At least $90 \%$ show abnormalities of the electroencephalogram (EEG) and $20-25 \%$ have epileptic seizures.

Changes in the brain. Using histological techniques, deficient myelination in some cases of phenylketonuria has been reported (Crome \& Pare, I960; Jervis, I963). Chemical estimation of myelin lipids has revealed a marked deficiency in the white matter of the brain, even in some cases considered normal by histological examination (Crome, Tymms \& Woolf, 1962). It seems clear that phenylalanine or its 'abnormal' metabolites, or both, hinder the deposition of myelin in the brain; it is not known whether this leads to mental retardation, etc. or whether the morphological change and mental and neurological features are different effects of a common cause, but there can be no doubt that they are related. 
Phenylalanine and/or some of its 'abnormal' metabolites inhibit enzymes essential for the production of the synaptic transmitters dopamine, noradrenaline, serotonin and $\gamma$-aminobutyric acid (Fellman, 1956; Davison \& Sandler, I958; Hanson, I959; Boylen \& Quastel, I96ı; Tashian, 196ı; McKean, Schanberg \& Giarman, r962). This reduction in neurohormone production should be rapidly reversible when the concentration of phenylalanine falls and may account for the dramatically rapid improvement in seizure frequency, EEG and behaviour often seen when an older phenylketonuric is first given a low-phenylalanine diet. 'The myelin deficiency may account for the irreversible component of the mental retardation.

Treatment. In $195^{1}$ the theory was put forward that the mental and neurological features characteristic of phenylketonuria were the result of intoxication by phenylalanine or its 'abnormal' metabolites and could be prevented or ameliorated by a diet low in phenylalanine (Woolf \& Vulliamy, $195^{\mathrm{r}}$ ). An economic form of such a diet was devised (Woolf, Griffiths \& Moncrieff, I955) and has now been given to several hundred phenylketonurics. The results of such treatment from earliest infancy are: normal or nearly normal IQ, absence of epileptic seizures, normal EEG and normal, non-psychotic behaviour (Woolf, Griffiths, Moncrieff, Coates \& Dillistone, I958; Berman, Graham, Eichman \& Waisman, I96r; Woolf, I962b, 1963; Sutherland, Umbarger \& Berry, ı 966; Baumeister, 1967; Hsia, 1967).

Some early difficulties with infants on the diet have been traced to too low an intake of phenylalanine (Medical Research Council: Conference on Phenylketonuria, I963; Umbarger, Berry \& Sutherland, I965; Cockburn, Sherman, Ingall \& Klein, 1965). At one time it was thought that deficiency of choline, folic acid, vitamin $\mathrm{E}$ or essential fatty acids might account for the lesions, but this now seems unlikely. These unintentional experiments have demonstrated that phenylalanine is an essential amino acid for the human infant and that treatment requires careful biochemical control.

In some cases treated phenylketonurics have returned to a normal diet after a few years. When treatment has started relatively late, there is often a rapid deterioration to the state before treatment started. Some phenylketonurics, treated from very early infancy, do not appear to deteriorate if they are returned to a normal diet after a few years, but it is possible that very slow detcrioration, detectable over several years, occurs even here (Horner, Streamer, Alejandrino, Reed \& Ibbott, I962; Murphy, I963; Murphy, 1967, private communication; Vandeman, I963; Koch, I 964; Solomons, Keleske \& Opit $z$, r966; Hudson, I967).

Genetics. For genetic counselling it is important to be able to identify carriers of the phenylketonuria gene. Determining the metabolism of an intravenous loading dose of phenylalanine enables this to be done with from 94 to $99 \%$ confidence (Woolf, Cranston \& Goodwin, 1967 ).

Study of phenylketonurics living in institutions indicated an overall prevalence of $I$ in 20000 in Great Britain and the USA. Carter \& Woolf (I96I) suggested that the disease was sixteen times as common in West Scotland and Southern Ireland as in Southeast England, the prevalence being perhaps I:3200 in West Scotland. 
Dietary treatment, if successful, results in a normal individual who can marry and have offspring, thus increasing the frequency of the phenylketonuria gene in subsequent generations The eugenic argument is that we should therefore not treat phenylketonurics. However, it will take ninety-eight generations (say 2500 years) or longer to double the gene frequency in Great Britain (Woolf \& Goodwin, 1967)-by that time some appropriate solution will surely have been reached.

Variant forms of phenylketonuria In atypical phenylketonuria the IQ is in the normal range (Cowie, I95 I Coates, Norman \& Woolf, I957; Woolf, Ounsted, Lee, Humphrey, Cheshire \& Steed, r96r; Woolf, 1963) The concentration of phenylalanine in the blood is often lower than in classical phenylketonuria, reinforcing the intoxication theory.

Hyperphenylalaninaemia is the name recently given to a condition characterized by a temporary high concentration of phenylalanine in the blood (from 10 to 80 $\mathrm{mg} / \mathrm{r} 00 \mathrm{ml})$ lasting a few months and followed by a lower concentration $\left(3^{-12} \mathrm{mg} /\right.$ $100 \mathrm{ml}$ ). These values may be contrasted with the normal (about $\mathrm{I} \mathrm{mg} / \mathrm{I} 00 \mathrm{ml}$ ) and those in classical phenylketonuria $(20-40 \mathrm{mg} / 100 \mathrm{ml}$ after $\mathrm{r}$ or 2 years of age). Clinically, some children with hyperphenylalaninaemia are normal, some moderately retarded and a few severely retarded (Schneider \& Garrard, I966; Kennedy, Wertelecki, Gates, Sperry \& Cass, I967; Hsia \& O'Flynn, r967; Scriver, I967). The liver, both in hyperphenylalaninaemia and in atypical phenylketonuria, contains appreciable phenylalanine hydroxylase activity though far less than in the normal,

Maternal phenylketonuria. A few phenylketonuric women have given birth, the offspring being, in general, non-phenylketonuric. In some cases the children were normal (Woolf et al, $196 \mathrm{I}$ ), in others they were moderately retarded (Mabry, Denniston \& Coldwell, I966). The intelligence of the offspring appears to be inversely correlated with the concentration of phenylalanine in the maternal blood. It appears that the foetal brain can be damaged to some extent by exposure to a phenylketonuric milieu in utero if the concentrations are high enough. Women with phenylketonuria should be treated with a diet low in phenylalanine throughout pregnancy, aiming to keep the blood phenylalanine level below $10 \mathrm{mg} / \mathrm{roo} \mathrm{ml}$. This applies, of course, to any successfully treated female phenylketonuric whose dietary treatment has been relaxed.

Screning programmes. For optimum results dietary treatment must be started in earliest infancy, long before any clinical signs are manifest and when phenylketonuria can be diagnosed only by chemical tests (Woolf et al. I958). It follows that the whole population of newborn infants must be screened by appropriate tests. This is now being done in many countries, including Great Britain. In Southern Ireland and in Glasgow a prevalence of I phenylketonuric in every 4000 live births is being found (J. Scott, 1967 , personal communication; Cahalane, 1968) in close agreement with the calculated figure (Carter \& Woolf, 1961). In the USA a prevalence of $I$ in 10000 is found; about one-third of these have hyperphenylalaninaemia rather than phenylketonuria, but even allowing for this there is a discrepancy with the figure $\mathbf{I}$ in 20000 based on surveys of institutions for the 
retarded (MacCready, 1967). Critics of the effects claimed for dietary treatment point to this discrepancy and suggest that half of all 'phenylketonurics' would not be mentally retarded even if untreated; they suggest that treatment may appear to be efficacious only in those who would have been normal without treatment (Bessman, 1966). This seems unlikely on several grounds.

(I) Statistical: the number of phenylketonurics successfully treated from early infancy is too high for it to be probable that all of them fall in this 'unaffected' group.

(2) Genetic: the variant forms of phenylketonuria run fairly true to type within sibships, but some successfully treated phenylketonurics have untreated older sibs who are very scverely affected.

(3) Clinical: the older, clinically affected, phenylketonuric child often shows marked neurological improvement on a low-phenylalanine diet.

\section{Homocystinuria}

Homocystinuria was first described by Carson \& Neill (1962) in Belfast and, simultaneously and independently, by Gerritsen, Vaughn \& Waisman (1962) in Wisconsin. The first cases were severely retarded mentally, had epileptic seizures and other neurological abnormalities, eye changes including prolapsed lenses, a tendency to thrombosis and bone abnormalities. In a later series of thirty-eight homocystinurics, Schimke, McKusick, Huang \& Pollack (x965) found twenty-two to be mentally retarded to various degrees and sixteen to be of normal intelligence.

Biochemistry. Methionine is normally demethylated to homocysteine which reacts with serine to form cystathionine, a reaction catalysed by the enzyme cystathionine synthetase. Cystathionine is then converted into cysteine which is in equilibrium with cystine. In homocystinuria the enzyme cystathionine synthetase is absent or virtually inactive and homocysteine therefore accumulates in the blood and tissues where it is in equilibrium with the disulphide form-homocystine. Much homocysteine is methylated to methionine which reaches high concentrations in the tissues and body fluids.

Cystathionine is normally present in highest concentration in parts of the brain and it may be necessary for normal activity of nerve cells. Homocystinurics lack cystathionine synthetase and, in the two patients examined, the brain contained very little cystathionine. It is not known whether the clinical features of homocystinuria result from a toxic excess of homocysteine or of methionine, or of both, or from a deficiency of cystathionine. It is not practicable to increase the cystathionine content of the brain - if this very expensive amino acid were fed it would be rapidly excreted in the urine. It is in any event difficult to believe that so many homocystinurics would be of normal or nearly normal intelligence if, lacking cystathionine as they do, this amino acid were essential for normal brain function. However, it is possible that though cystathionine synthetase is absent from the liver in all cases and from the brain in some, this enzyme (or an isozyme) occurs in the brain in some homocystinurics; cystathionine synthetase has been found in the lens of the eye in one patient (Gaull, 1967 ). 
On the theory that the clinical features result from an intoxication, treatment with a diet low in methionine is being tried in a few cases (Brenton, Cusworth, Dent \& Jones, I966; Perry, Dunn, Hansen, MacDougall \& Warrington, I966; Komrower, 1967). As in phenylketonuria, it is necessary to treat from earliest infancy for optimum results, necessitating a screening programme for homocystinuria. When treating it is necessary to give supplementary cystine which becomes an essential amino acid in homocystinuria. It is too early to assess the results of treatment, but so far they are promising.

\section{REFERENCES}

Baumeister, A. A. (I 667$)$. Am. F. ment. Defic. 71, 840 .

Berman, P. W., Graham, F. K., Eichman, P. L. \& Waisman, H. A. (1961). Pediatrics, Springfield 28, 924 .

Bessman, S. P. ( ( g66). F. Pediat. 69, 334.

Beutler, E., Baluda, M. \& Donnell, G. N. (1964). F. Lab. clin. Med. 64, 694.

Beutler, E., Baluda, M., Sturgeon, P. \& Day, R. (1965). Lancet i, 353.

Boylen, J. B. \& Quastel, J. H. (I 96r). Biochem. F. 80, 644 .

Brenton, D. P., Cusworth, D. C., Dent, C. E. \& Jones, E. E. (1966). Q. Fl Med. 35. 325.

Cahalane, S. F. (1968). Archs Dis. Childh. (In the Press.)

Carson, N. A. J. \& Neill, D. W. (1962). Archs Dis. Childh. 37, 505.

Carter, C. O. \& Woolf, L. I. (196r). Ann. hum. Genet. 25, 57.

Coates, S., Norman, A. P. \& Woolf, L. I. (1957). Archs Dis. Childh. 32, 3 I 3.

Cockburn, F., Sherman, J. D., Ingall, D. \& Klein, R. (1965). Proc. Soc. exp. Biol. Med. rז8, 238.

Cowie, V. A. (195I). Lancet i, 272.

Crome, L. \& Pare, C. M. B. (Ig60). F. ment. Sci. I96, 862.

Crome, L., Tymms, V. \& Woolf, L. I. (1962). F. Neurol. Neurasurg. Psychiat. 25, 43.

Davison, A. N. \& Sandler, M. (1958). Nature, Lond. 181, I86.

Fellman, J. H. (1956). Proc. Soc. exp. Biol. Med. 93, 413.

Fölling, A. (1934). Hoppe-Seyler's Z. physiol. Chem. 227, 169.

Garrod, A. E. (1908). Lancet ii, I.

Gaull, G. E. (1967). Am. \%. Dis. Child. 113, 103.

Gerritsen, T., Vaughn, J. G. \& Waisman, H. A. (1962). Biochem. biophys. Res. Commun. 9, 493.

Gerritsen, T. \& Waisman, H. A. (1966). In The Metabolic Basis of Inherited Disease, p. 420. [J. B. Stanbury, J. B. Wyngaarden and D. S. Fredrickson, editors.] New York: McGraw-Hill Book Company.

Gitzelmann, R. (1965). Lancet ii, 670.

Hanson, A. (1959). Acta chem. scand. 13, 1366.

Horner, F. A., Streamer, C. W., Alejandrino, L. L., Reed, L. H. \& Ibbott, F. (I962). New Engl. $\mathscr{~}$. Med. 266, 79 .

Hsia, D. Y.-Y. (1967). Devl. Med. छ Child Neur. 9, 53 I.

Hsia, D. Y.-Y. \& O'Flynn, M. E. (I967). Metabolism 16, 99.

Hsia, D. Y.-Y. \& Walker, F. A. (1961). F. Pediat. 59, 872.

Hudson, F. P. (1967). Archs Dis. Childh. 42, I98.

Jervis, G. A. (1963). In Phenylketonuria, p. 96. [Lyman, F. L. editor.] Springfield, Ill.: Charles C. Thomas.

Kennedy, J. L. Jr, Wertelecki, W., Gates, L., Sperry, B. P. \& Cass, V. M. (1967). Am. \%. Dis. Child. I $13,16$.

Koch, R. (1964). Am. F. Dis. Child. ro7, 537.

Komrower, G. M. (1967). Am. F. Dis. Child. $1 r_{3}, 98$.

Mabry, C. C., Denniston, J. C. \& Coldwell, J. G. (1966). New Engl. F. Med. 275, 1331.

MacCready, R. A. (1967). In Phenylketontria and Allied Metabolic Diseases. Proceedings of the Conference held at Washington, DC, 6-8 April 1966, p. 157. [J. A. Anderson and K. F. Swaiman, editors.] Washington, DC: US Department of Health, Education and Welfare, Children's Bureau.

Mckean, C. M., Schanberg, S. M. \& Giarman, N. J. (1962). Science, N.Y. 137, 604.

Medical Research Council: Conference on Phenylketonuria (I963). Br. med. \%. i, I69I.

Murphy, D. (1963). Irish f. med. Sci. p. 355.

Perry, T. L., Dunn, H. G., Hansen, S., MacDougall, L. \& Warrington, P. D. (1966). Pediatrics, Springfield 37, 502 . 
Schimke, R. N., McKusick, V. A., Huang, T. \& Pollack, A. D. (1965). F. Am. med. Ass. I93, 7II.

Schneider, A. J. \& Garrard, S. D. (1966), F. Pediat. 68, 704.

Schwarz, V. (1960). Archs Dis. Childh. 35, 428.

Scriver, C. R. (1967). Pediatrics, Springfield 39, 764.

Segal, S., Blair, A. \& Roth, H. (1965). Am. F. Med. 38, 62.

Solomons, G., Keleske, L. \& Opitz, E. (1966). F. Pediat. 69, 596.

Sutherland, B. S., Umbarger, B. \& Berry, H. K. (1966). Am. F. Dis. Child. III, 505 .

Tashian, R. E. (1961). Metabolism 10, 393.

Umbarger, B., Berry, H. K. \& Sutherland, B. S. (1965). F. Am. med. Ass. 193, 784.

Vandeman, P. R. (1963). Am. J. Dis. Child. 106, 492.

Woolf, L. I. (1962a). Adv. clin. Chem. 5, r.

Woolf, L. 1. (1962b). Proc. Nutr. Soc. 21, 21.

Woolf, L. I. (1963). Adv. clin. Chem. 6, 97.

Woolf, I. I., Cranston, W. I. \& Goodwin, B. L. (1967). Nature, Lond. 213, 882.

Woolf, L. I. \& Goodwin, B. L. (1967). Lancet i, 2 16.

Woolf, i. I., Griffiths, R. \& Moncrieff, A. (I955). Br. med. \%. i, 57.

Woolf, L. I., Griffiths, R., Moncrieff, A., Coates, S. \& Dillistone, F. (I958). Archs Dis. Childh. 33, 31.

Woolf, L. I., Ounsted, C., Lee, D., Humphrey, M., Cheshire, N. M. \& Steed, G. R. (Ig6r). Lancet ii, 464 .

Woolf, L. I. \& Vulliamy, D. G. (I95I). Archs Dis. Childh. 26, 487.

The influence of protein-calorie deficiency on the central nervous system

By R. J. C. STEWAR'T, Department of Human Nutrition, London School of Hygiene and Tropical Medicine, Keppel Street, London, WCI and B. S. PlatT, Human Nutrition Research Unit, National Institute for Medical Research, Mill Hill, London, $N W_{7}$

As apathy, listlessness, irritability and general misery are such constant manifestations of protein-calorie deficiency disease in man (Clark, 195 I Platt, 1954-5; Trowell, Davies \& Dean, I 954) it is surprising that until recently there had been few investigations into the effect of protein-calorie deficiency on the nervous system. The fact that the brain is large relative to the rest of the body (Brown, 1965) and that recovery from neurological disturbances appears to be complete has been accepted by many observers as evidence of a favoured status for the brain. Food restriction, however, has been shown to produce changes in the central nervous system of man (Jackson, 1925), mice (Andrew, r941), cats (Ferraro \& Roizon, 1942), rats (Dobbing, 1964) and pigs (Dickerson, Dobbing \& McCance, 1967). Changes have also been described in pigs fed ad lib. on diets of low protein value (Platt \& Stewart, I960; Lowrey, Pond, Barnes, Krook \& Loosli, I962; Platt, Pampiglione \& Stewart, I965).

Most of the changes would appear to be reversible but the gliosis found in deficient pigs (Meyer, Stewart \& Platt, 196r; Platt et al. 1965) and the impaired maze-solving performance of rehabilitated pigs (Barnes, 1967) raise doubts about a complete return to normality. It has become clear that the severity of the changes could be modified by (a) the protein value of the diet, (b) the amount of diet consumed and (c) the age at which the deficiency was established. For instance, pigs given diets of low protein value from the I gth day of age showed less severe changes than those given similar diets at 14 days but more severe changes than those given 